\title{
On the Current Situation and Practical Path of "Integration" of Patriotic Education in Universities, Middle Schools, Primary Schools and Kindergartens - Research and Analysis Based on S City
}

\author{
Bin Wang ${ }^{1}$ \\ School of Arts, Sichuan Normal University, Chengdu 610000, Sichuan, China
}

\begin{abstract}
The construction of "integrated" new system of patriotism education in universities, middle schools, primary schools and kindergartens is an important policy to solve the problem of "who to train people, what kind of people to train and how to cultivate people", and it is an important project to strengthen the cultivation of socialist core values. This paper analyzes the basic practice and successful experience of patriotism integration education in universities, middle schools and kindergartens in S City, and puts forward that in the new era, the education of patriotism integration in colleges, middle schools and kindergartens should adhere to the "four following laws".
\end{abstract}

Keywords: College; Middle School; Primary School; Kindergarten; Education for Patriotism; Integrated; Practice Path

\section{The necessity of patriotism education in schools}

At all times and in all over the world, loyalty to the country is the duty of every citizen. Therefore, patriotism is also a civic obligation, the most basic civic morality, the bottom line of morality, and the embodiment of citizens' responsibility for the security and dignity of the motherland.

\subsection{Patriotism education is the need of national development}

Patriotism is an important political principle. The development of patriotism is conducive to the development of the country. The reason why the important political principle of patriotism is that human beings have gradually formed and developed in the long-term practice of social life. The concept of the motherland and loving the motherland came into being after the emergence of class and country, and gradually developed into a clear patriotic thought. In many times of Anti Japanese War, China can win, let the motherland have today, it is a peaceful era, but patriotism is still the theme. In politics, only with the motherland's development in mind, can we make decisions conducive to the development of the motherland, make the motherland more prosperous and strong, and make the people's life more happy.

\subsection{Patriotism education is the need of national rejuvenation}

The Chinese nation has a long history of cultural tradition, is an excellent nation with strong national cohesion and national pride. Patriotism has always been the traditional virtue of the Chinese nation. With the remarkable improvement of China's comprehensive national strength and its increasing role and influence on the world stage, the Chinese nation is standing in the forest of world nations with a more lofty attitude. In this era, patriotism is more prominent in the process of national rejuvenation. We must guide students to transform patriotism passion into rational patriotic action while conducting patriotism education for students. We should also integrate patriotism concept in national rejuvenation into a series of patriotic education activities.

\subsection{Developing patriotism is the need of students' all-round development}

Students are the future of our country and the focus of patriotic education. To strengthen the education of patriotism and cultivate the spirit of patriotism is helpful for students to firmly establish correct world outlook, outlook on life and values, to carry forward and cultivate students' national spirit, to enhance their national self-esteem, self-confidence and pride, to improve their patriotism awareness, correct possible thinking deviation and bad behavior, and gradually grow into investment They are qualified personnel for socialist modernization.

1 About the author: Bin Wang(1992- ), male, born in Ya'an, Sichuan Province, is a counselor and teaching assistant of the College of Arts, Sichuan Normal University. He is mainly engaged in the research of Ideological and political education of college students.

This is an open-access article distributed under the terms of the Creative Commons Attribution Non-Commercial License

(http://creativecommons.org/licenses/by-nc/4.0/), which permits unrestricted non-commercial use, distribution, and reproduction in any medium, provided the original work is properly cited. 


\section{The basic practice of patriotism education in universities, middle schools, primary schools and kindergartens in S City}

S city always takes "moral education" as the starting point and end point of its work, and actively adapts to the needs of the new situation of economic and social development. On the basis of grasping the construction of organizational system, it focuses on the selection of education carriers and methods for patriotism education, forming the basic path of "segmented implementation and stage connection".

\subsection{Kindergarten stage: focus on cultivating students' patriotic feelings}

Children's patriotic enlightenment education is a comprehensive and all-round educational activity. S City accurately grasps the development law of children's cognition, emotion and behavior vertically, guides the kindergartens in different districts (cities and counties) to pay attention to creating situations, take various ways to strengthen education effect, and carry out patriotism education suitable for children's characteristics, regional characteristics and school characteristics in a planned and targeted way. The main methods are as follows: Firmly implement the position of children's patriotism education scientifically; Establishing the content system of " $1+n$ " children's patriotism education; Create regional environment and expand the space of children's patriotism education Carry out theme activities to help cultivate the sprout of patriotism Develop characteristic courses and put patriotism education in activities.

\subsection{Primary school stage: focus on cultivating students' patriotic emotion consciousness}

Primary school students are in the formative period of ideology, which is the initial stage of forming value evaluation, moral cognition and critical ability. The main form of children's thinking development in primary school stage is the transition from concrete image thinking to abstract logical thinking. At this time, students' logical thinking has just been developed, and they have not been able to understand and accept the abstract knowledge far away from life experience. The main methods are as follows: Formulate education objectives scientifically and clarify the main tasks of patriotism education; To make a division plan and dig deeply into patriotism education resources of various disciplines; Strengthen the model demonstration and provide the materialized mode required by the standard of thought, words and deeds; Pay attention to habit cultivation education and lay a solid emotional foundation for patriotism education; Pay close attention to activity education to stimulate pupils' patriotic emotion and will.

\subsection{Middle school stage: focus on cultivating students' rational cognition of patriotism}

With the maturity of physiology and the deepening of education, middle school students' curiosity and desire to explore social problems will gradually deepen. The stage of middle school students' physical and mental development determines that the patriotic education of middle school students must be carried out in stages according to the characteristics of different ages. S city has determined the main task of patriotism education in middle school, that is, to cultivate students' rational cognition of patriotism. The main methods are as follows: Adhere to the combination of history education and reality Education; Adhere to the combination of emotional motivation and rational guidance; Adhere to the combination of theoretical education and practical education; Adhere to the combination of traditional education and modern science and technology.

\subsection{University stage: the specific practice of guiding students' Patriotism}

What the college students lack is no longer the explosion of emotion, the deepening of cognition and the establishment of belief, but the opportunity to externalize these contents into behavior. In this case, if the school still focuses on improving students' moral cognitive level, it is likely to be alienated into meaningless preaching. Therefore, S City focuses on guiding college students to show their understanding and love of the country as behavior, and then safeguard the national interests at the behavior level. The main methods are as follows: Provide channels to participate in school public affairs and cultivate college students' public spirit; Establish social practice base and build a practical platform for college students' patriotic dedication; Carrying out career planning education to guide the coupling of college students and national development direction.

\section{Four key points of patriotism education in universities, middle schools, primary schools and kindergartens}

Only in the community can individuals achieve all-round development. The integrated system of patriotism education in University, middle school, primary school and kindergarten refers to the integrated education practice system of university middle school, primary school and kindergarten, which takes patriotism education object and educational institution as a whole and carries out according to the law of education.

\subsection{Follow the law of the generation and development of human nature}

The patriotism education in line with human nature is the education with true, good and beautiful connotation, which is bound to be widely accepted and successful; the patriotic education against human nature is full of false, evil and ugly education, which is inevitably rejected and failed by people. The object of patriotism education in college, middle school, primary school and kindergarten is the students who are growing up. Human nature in this period experienced a very important process of generation and development, with its own law of generation and development. Therefore, patriotism education in universities, middle schools, primary schools and kindergartens must follow the law of the generation and development of human nature.

\subsection{Follow the law of generation and development of moral cognition}

Piaget, an important representative of moral cognitive theory, said: "all morality is composed of various rules. The essence of morality can be found in the individual's respect for these rules." The deepening of people's understanding and understanding of 
these rules is an important sign of people's moral maturity. The important goal of patriotism education is to cultivate people's good patriotic cognitive ability and positive patriotic thinking habits. People's moral cognition is constantly developing and changing, and has its own law of generation and development. Therefore, patriotism education in University, middle school, primary school and kindergarten must adapt to the generation and development law of people's moral cognition, and establish the contents and methods of moral cognition education according to the requirements of this law.

\subsection{Follow the law of generation and development of moral emotion}

Moral structure includes not only moral cognition but also moral emotion. In a certain sense, the direct motive force of people's moral behavior is moral emotion, not moral cognition. The generation and development of people's moral emotion has rules to follow. Moral emotion is a development process from narrow to generous, from single to rich, from shallow to profound. Therefore, the construction of University, middle school, primary school and kindergarten patriotism education integration system must conform to the law of moral emotion generation and development.

\subsection{Following the law of generation and development of moral behavior}

The elements of moral structure include not only moral cognition, moral emotion, but also moral behavior. Moral cognition and moral emotion should be expressed through moral behavior. The development of moral behavior is a continuous entity with its inherent law of generation and development. Therefore, the patriotic education of University, middle school, primary school and kindergarten is an integrated process in accordance with the law.

\section{Acknowledgements}

Fund projects: This paper is a phased research result of the research project of Sichuan Normal University's ideological and political work in 2020, Research on the innovation of ideal and belief education mechanism of College Students' Party activists in the new era" (Project No.: 2020-13).

\section{References}

1. LAN Meirong, Lu LIGO. A review of the research on patriotism theory.

2. Chen Hongtao, Chen Xuexian. Challenges and actions of patriotic education in primary and secondary schools.

3. Sun Yinguang. The logical level and practical strategy of patriotic education.

4. Li Jian. Four dimensions of constructing the integrated moral education system of middle schools, primary schools and kindergartens with Chinese characteristics in the new era. 